\title{
Social Criticism in Mark Twain's the Adventures of Huckleberry Finn
}

\author{
Dr. Ibrahim Shalabi \\ University of Hail, Department of English, Saudi Arabia
}

\begin{abstract}
It is not implied by social criticism that Twain's novel is to be read as a sociological treatise or an 'unedited transcript of reality' or even a mere 'realistic recital of facts, even though the writer himself called it a 'true book'. The purpose of this article is to show how American life of those days was translated into fiction with its symbolic depth and resonance. It is the latter quality that gives the book the status in literature. In fiction, symbolism is the most important tool for recording the world around us. It must be remembered that a writer is in no way severed from the world and nor is art an abstract skill but as Mathew Arnold says " $a$ criticism of life".
\end{abstract}

Keywords: social criticism, symbolism, American Literature, discrimination.

\section{INTRODUCTION}

Life and literature have never been at odds nor ever been thought so since the conception of art for isn't literature the mirror or the window to the world? If such a conflict really existed, most black American writers would not have written at all. Ralph Ellison in his work Shadow and Act (1936) for example, recognizes no dichotomy between art and protest and asserts that 'social protest is not antithetical to art'. But there must be a fundamental connection between artistic means, that is technique and discipline, and social and moral conviction. It is only when an aesthete approaches politics as if it were a poem, or when the political activist approaches the poem as it were a leaflet, that the trouble starts.

It can be argued that all that is great in American literature comes out of a profound confrontation of social facts. One thinks, for example, Of Moby Dick and Leaves Of Grass in the nineteenth century, similarly, in the twentieth century the plays of Arthur Miller - The Death of a Salesman; All MY Sons and The Price, to name a few, the plays of Edward Albee - The American Dream, Who's Afraid of Virginia Woolf and The Delicate Balance, all aim at converting social issues into drama. Even The Zoo Story, which has been placed in the category of absurd drama, is a commentary on social dilemmas.

\section{THE AMERICA OF MARK TWINS}

The reason why there is no confrontation of social facts in Henry James is that he had a great fascination for "the items of high civilization" as they existed in Europe. Henry James came from a different America, the one that was dominated by European culture, as against the America of Mark Twain who identified himself with the culture of the frontier. Besides, Twain's subject was man in society and the alienated man ("social pariah" in Leslie Fiedler's words). James's interest, on the other hand, lay in the inner workings of his characters, what he himself described as the "interest behind the interest." This search into the interest behind the interest made up the drama staged in the consciousness and it became an almost artistic principle with James to present the drama with only the essential clues.

There has always been a cultural bias in Mark Twain ever since Van Wyck Brooks (1933) published The Ordeal of Mark Twain. Brooks considered Twain a great artist possessing native gifts but subordinating these gifts to the forces of Puritanism and the frontier. Bernard DeVoto (1942) in his book which was a rejoinder to Brooks' book, identified Mark Twain with the frontier and considered Twain's books as having in them "something eternally true to the core of the nation's life." Even the literary historians considered Mark Twain the epitome of American culture. Vernon Louis Parrington (1972) for example, called Twain "an immensely significant American document ... a mirror 


\section{Dr. Ibrahim Shalabi}

reflecting the muddy cross- currents of American life". Henry S. Canby, (1951) reviewing DeVoto's book, felt that DeVoto had the right key to the understanding of Mark Twain. In his book, Turn West, Turn East, Canby says that "Mark Twain was offensively American' (p xii) F.R. Leavis (1958) while agreeing with the broad outlines of Marius Bewley's thesis finds in Twain, particularly in Huckleberry and Pudd'nhead Wilson the presence of a mature and full heritage of civilization. He finds as much complexity of ethical valuation of the complex tradition of society in Mark Twain as Bewley seems to have found in Hawthorne and Henry James.

What has been attempted here is to pinpoint the moral center of the book and to relate it to similar problems in American society of Twain's times without referring it to any "psychic wound" in the author, or the "frontier hypothesis" or the "archetypal images and myths" in American culture. Therefore, the area of discussion is limited to the white man's relationship to the black American which has been symbolized by Huck and Jim in the novel.

\section{BLACK WHITE AMERICA}

The problem of the black American had been on Twain's mind for a long time before he conceived the plan of Huckleberry Finn. ${ }^{1}$ In the early seventies he submitted to William Dean Howells - his moral arbiter and friend - a short piece dealing with the life of slaves with the following note: "I enclose $A$ True Story which has no humor in it. You may pay as lightly as you choose for that, for it is rather out of my line". Howells found the story "extremely good and touching, and with the best and the realest kind of black talk in it," and published it in the November 1874 issue of The Atlantic. The story is told by all black women who is separated from her favorite son, and after a Iapse of twenty-two years is reunited when the master runs away at the 'news of the advancing Union armies. Justin Kaplan in his Mr. Clemens and Mark Twain $(1966,181)$ considers this story one of Mark Twain's best, and feels that it, in many ways, foreshadows Huckleberry Finn "The rugged truth of the sketch", commented Howells, "leaves all other stories of slave life infinitely far behind, and reveals a gift in the author for the simple, dramatic report of reality which we have seen equally in no other American writer." (p.180) Twain had the opportunity of working out this problem on a wider canvas - in the background of the dominant attitude of the people - in Huckleberry Finn and Pudd'nhead Wilson. Both these novels deal with the fate of the blacks in a white society. If the question of freedom is the source of action for Jim and Huck, the question of environment as shaping the man is the source of action for Tom Chambers and Roxanat in Pudd'nhead Wilson.

\section{The MORAL DePTH in HUCKLEBERRY FinN}

It is the undercurrent of the tragedy of slavery for both black and white that gives Huckleberry Finn its moral depth. The broad framework is the emergence of personal freedom and individual responsibility in a society which is dominated by conventional morality. Within this broad framework the story of Huck and Jim's quest for freedom is unfolded.

Jim's flight from society was occasioned by his fear that he might be sold down to Orleans into a harsher slavery, where they work a "nigger" to death, for "eight hund'd dollars which 'uz sich a big stack o' money she (Miss Watson) could'n resis'."(p.50) However, it was not merely the fear of being sold into a worse kind of slavery, although that provided the initial action, that made him run away from Miss Watson: it was also a hidden, suppressed desire for freedom which suddenly sprang up to the surface when he found a sympathetic heart. When Huck talked of his becoming rich again, Jim said

Yes-en I's rich now, come to look at it ! I owns my self, en I's wuth eight hund'd dollars. I wisht I had de money, I wouldn' want no mo,."(p.54)

Jim was aware of the consequences of his not reaching the free land and his being caught again. He "didn't' want nobody to pick him up, and take him into slavery again". (p.123) The prospect of reaching a free land filled him with unbounded joy.

He said he'd be mighty sure to see it, because he'd be a free man the minute he seen it, but if be missed he'd be in the slave country again and no more show of freedom. Every little while he jumps up and says:

Dah she is? 
...Jim said it made him all over trembly and feverish, too, to hear him, because I begun to get it through my head that he was most free-and who was to blame for it. Why, me. I couldn't get that out of my conscience, no how nor no way (p.92-93)

Even Huck's flight from Miss Watson, the Widow Douglas and his father (in fact, the whole community in relation to which he is a young outcast) was not a flight from physical danger alone. "All I wanted was a change", he told Miss Watson. "I wasn't particular". As Leslie A. Fiedler says in his Love and Death in the American Novel put it, Huck is not an "open rebel, a self-declared enemy of society" yet he wanted to be free "again and all by ourselves on the big river and nobody to bother us". (p.555)

\section{MAIN ELEMENTS IN HUCKLEBERRY FinN}

Although Henry Nash Smith points out three main elements in Huckleberry Finn in his book Mark Twain: The Development of a Writer, he considers the developing characterization of Huck as the major element in the book. The other two elements are : Huck's and Jim's adventures in their flight toward freedom: Jim is running away from actual slavery, Huck from the cruelty of his father, from the well-intentioned 'civilizing' efforts of Miss Watson, from respectability and routine in general; and social satire of the towns along the river. But it seems that Huck and Jim's adventures in their quest for freedom and Huck's awareness of his moral responsibility are only twin aspects of the same. The other element, social satire of the towns, has been presented to serve as a fitting background to man's cruelty to man, that is the white man's treatment of the black man. Thus Jim's quest for freedom is not unrelated to Huck's growth in moral insight and vice versa. It is because the focus of critical evaluation has been shifted from the white-black relationship to that of Huck's developing characterization mostly unrelated to Jim's quest for freedom and social satire that the novel has not been viewed from the angle.

The society Jim had run away from was a society which not only believed in but also practiced discrimination between a "nigger" and a white man;. The phrase "free nigger" was enough to scandalize white Americans. This is what Pap thinks of a "free nigger".

Thinks I, what is the country a coming to? It was lection day, and I was just about to go and vote myself, if I warn't too drunk to get there; and when they told me there was a State in this country where they'd let that nigger vote. I drawed out... And to see the cool way of that nigger - why he wouldn't give me the road oif I hadn't showed him out of the way. I says to the people, why aint this nigger put up at auction and sold? That's what I want to know. And what do you reckon they said? Why, they said he couldn't be sold till he'd been in the State six months, and he hadn't been there that long yet...Here's a govment that calls itself a govment and let on to be govment, and thinks it is a govment, and yet's got to set stock-still for whole six months before it can take hold of a prowling, thieving, infernal, white-shirted free nigger, and -“(35)

\section{Radical Representations towards the RaCe Problem in HuCKLEberRy FinN}

But Huck Finn never thought "regular", never adopted the attitude of his father and the society that he represented. He was committed to help out Jim into freedom right from the beginning "even if people called him a low down Abolitionist". At Miss Watson's he refused to align himself with Tom Sawyer in his plan to tie up the sleeping Jim, His commitment to Jim and his freedom was complete when he promised Jim not to tell others of his escape.

Well, I did. I said I wouldn't, and I'll stick to it. Honest injun I will. People will call me a low down abolitionist and despise me for keeping mum - but that don't make no difference. I ain't going to tell, and I ain't going back there anyways. (p.50)

Henry Nash Smith writes that Huck's conscience was "the sum total of the fancied obligations, the foolish inhibitions, and the perverse constraints imposed on Huck by society". Ralph Ellison calls it the internalized representative of the community. This tension between Huck's commitment to Jim's freedom and humanity and the written and the unwritten code of the society of his time gave the novel its moral depth. In his Notebook Mark Twain called Huckleberry Finn a book of "mine where a sound heart and a deformed conscience come into collision and conscience suffers defeat". 


\section{Dr. Ibrahim Shalabi}

Huck, as also Mark Twain, was part of the "fabric of organized, acquisitive society", "the sick folk" and "the damned human race" that nurtured him. Mark Twain by holding radical views towards the race problem became an outsider who could view the problem both as an outsider and an insider. He became the most "desouthernized of Southerners", although he had always lived in a society where "the institution of slavery was unquestioned". Mark Twain soon realized ' through Huck Finn, that it was a mistake to consider the "dwarf conscience" as the "voice of God". He could, therefore, free himself from the tyranny of conscience only if he was able to maintain a critical distance from it. The conscience that unerring monitor can be treated to approve any wild thing you want it to approve if you begin its education early and stick to it.

By showing what Huck Finn considers he ought to do and what he is aware he must do (conscience and the sound heart) Twain situated in a single consciousness both the perverted moral code of a society built on slavery and the vernacular commitment to freedom and spontaneity. Twain was thus able to present the opposed perspectives as alternative modes of experience for the same character. As against the opposed perspective, Roxana's son in Pudd'nhead Wilson experienced both modes of experience. "Why were niggers and whites made?" Tom Chambers began to think. "What crime did the uncreated first nigger commit that the course of birth was decreed for him? And why is this awful difference made between white and black? How hard the nigger's fate seems, this morning! - yet until last night such a thought never entered my head."

Huck's conscience "went to grinding" and he began to analyze his attitude towards Jim. "I was trying to make my mouth say I would do the right thing and the clean thing and go and write to that nigger's owner and tell where he was: but deep down in me I knowed it was a lie - and He knowed it - I found that out". (p 209) He took a decision against his heart and wrote the letter to Miss Watson informing her where her runaway nigger was. He felt himself light and "all washed clean of $\sin$ " at least for the time being. Finally, he threw himself on the side of Jim.

I was a trembling, because I'd got to decide, forever, between two things, and I

knowed it. I studied a minute, a sort of holding my breath, and then say to

myself: "All right then, I'll go to hell - and tore it up." (p.210)

On the social plane it was a struggle with the problem poised by the clash between property rights and human rights, between what the community considered to be the proper attitude toward an escaped slave and Huck's knowledge of Jim's humanity, between direct human relationship of the frontier and the abstract, inhuman, market-dominated relationship fostered by the rising middle class which in Mark Twain's day was already compromising dangerously with the most inhuman e aspects of the defeated slave system. ${ }^{7}$ Twain by taking the final decision clearly showed that he was for human rights and on the side of humanity.

\section{IDEALIZED WORLD}

Towards the end of the novel, Huck realized that their search for an idealized world where Jim would have equality with white folks, and where the "irreparable breach between black and white" would be healed was impracticable and likely not to materialize in the present framework of society. He must realize the limits of freedom, not only for himself but also for Jim. This had already been suggested earlier in the novel by a very significant symbol-a steam boat. Huck and Jim were only half way in their quest for freedom when their lumber raft was run over by a steam boat (an image of the avenging society) and Huck had to dive deep (or was it diving deep into his sensibility, as Kaplan suggests?) in order to save himself. They were not able to restore their home again after that incident.

Fielder in End of Innocence (1971) considers the existence on the raft "a dream at whose heart lurks a nightmare", making the "impossible society" on the raft "unreal" although Huck felt that "there warn't no home like raft" and "You feel mighty free and easy and comfortable on a raft". The dream recedes: "the immaculate passion and the astonishing reconciliation become a memory and less (?) a regret..." Jim says to Huck, "it is too good to be true, Honey. It is too good to be true"

The last chapters of the novel pose a problem to the critics and must have posed a problem to Mark Twain himself. Since it was not possible for Mark Twain to reconcile the radical character of Huck Finn with the realistic compulsions of the world of St. Petersburg and Phelps plantation, he abandoned the compelling image of Huck and Jim on the "jraft", the image of an ideal society. But it would be too much to say that Huck's commitment to the vernacular values in the story were mere figments of the imagination, because Huck had exposed the established system of values in the process. 


\section{THE SuCCESS OF TWINS' WORK}

Mark Twain does seem to suggest that the white Americans must make a choice between coming to terms with institutionalized discrepancy and formulating new ideologies Twain had already committed himself to formulating new ideologies based on equality and humanity, although the details had not been spelled out. But the debate between the accepted moral stance of the society and Huck's humanism suddenly comes to a stop and Huck realizes the difficulty of making a clear decision under the circumstances. But he clearly rejects the claims which sanctify slavery. He is realistic enough to realize that alone he cannot change the monolithic structure of the society and decides to "light out for the territory ahead of the rest". The reintroduction of Tom can be understood only in this context. We learn at the end that Jim had already been freed by Miss Watson, but we are not told of her motives in freeing Jim. This obviously is no solution to the problem raised and analyzed during the novel, nor did Twain mean to suggest this as a way out of the impasse. At best it was a compromise.

Mark Twain succeeded in capturing not only the white man's attitude towards the Negro but also the humanity of Jim ("I knowed he was white inside"). Twain's emphasis is not on "a nigger like that is worth a thousand dollars" (the conventional attitude of the white) but on Jim as "a symbol of man" who is worried about his family as much as any white man would be. As soon as he was able to save enough money he would buy his wife and his two children out of slavery. By bringing into focus this aspect of Jim's personality, Twain forced the white men to come out of their "habitual states of consciousness" and look on Jim through the "sound heart" of Huck. The white men did not look Jim in the face because they mainly Iook down or look up, but mainly look away".

By placing the problem of racial conflict at the centre of the novel, Twain highlighted the reality of Negro existence as perceived by the white and the black in America. On the one hand, he pointed out the process of "institutionalized dehumanization" and, on the other, the human factor in a white boy's relationship with a black man. This was remarkable at a time when Negroes were treated like chattel. Tom (who is in reality Roxana's son) points this out in Pudd'nhead Wilson. "He (Judge Driscoll) is white; and I am chattel, his property, his goods, and he can sell me just as he would his dog" (p.55) Mark Twain was also able to point out the hidden springs of freedom in black Americans. Thus he was able to exert an influence upon America's moral consciousness.

At one stage in the story Huck tries to explain to Jim the meaning of the story of King Solomon and the two ladies but Jim refuses to accept Huck's interpretation. Jim says, "I knows what I knows". Huck only says, "I never seen such a nigger. If he got a notion in his head once, there wasn't no getting it out again."(p.83) Then he asks what he would say to the man who said to him Polly-voo-frenzy. Jim says "I wouldn't think nuff'n. I'd take en bust him over the head." Then he suddenly realizes that he is talking to a white boy, and changes his stance, "dat is if he warn't white. I wouldn't allow no nigger to call me that".(p.84) It is taken a step further in Pudd'nhead Wilson where Roxy after the "sickly nigger wench had been beaten up by the master for talking to Roxy, snatched the stick outen his han' en laid him flat." She even kept a knife to defend herself.

\section{Conclusion}

Huck is the only person in the white society who is independent in the community because he sees the profound gulf that separates the black from the white. Is it not, then, the peculiar construction of the white man's inner eyes. Those eyes with which they look through their physical eyes upon reality that prevents them from seeing the object clearly? Even the abolitionists were not able to make the white Americans aware of this 'moral distortion".

Mark Twain seems to suggest that American reality can be defined only when the black reality is taken into account. Mark Twain hinted at this but since he could not be an open rebel - perhaps the time was not ripe - he only suggested it through the character of Jim. If the white Americans have to achieve their identity, they will have to come to terms with this "alien passion". Mark Twain made a beginning in this direction. 


\section{REFERENCES}

[1] Brooks, V. W. (1933). The Ordeal of Mark Twain. New York, Dulton.

[2] Canby, H. S. (1951). Turn West Turn East. Boston: Houghton Miffin.

[3] Devoto, B. (1942). Mark Twain's America. Cambridge Mass: Harward University Press.

[4] Kaplan, J. (1966). Mr Clemens and Mark Twain. New York: Simon and Schuster.

[5] Smith, H. N. (1962). "A Sound Heart and a Deformed Conscience" in Mark Twain: The Development of a Writer. Cambridge Mass: Belknop Press.

[6] Fiedler, L. (1960). Love and Death in American Novel. New York: Criterion.

[7] (1971). Collected Essays of Leslie Fiedler. New York: Stein Day Publishers.

[8] Honoells, W, D. (1910). My Mark Twain. New York: Harper Brothers.

[9] Parrington, V, L. (1927). Main Currents in American Thought, Vol. II

[10] Twain, M. (1986). The Adventures of Huckleberry Finn (Norton Edition) New York: Prentice Hall. 